\title{
Diabeteses dyslipidaemia és atherosclerosis
}

\author{
Márk László dr., Dani Győző dr. \\ Békés Megyei Pándy Kálmán Kórház, II. Belgyógyászat-Kardiológia, Gyula
}

\begin{abstract}
A diabetes mellitus gyakorisága és ezzel együtt népegészségügyi jelentősége is folyamatosan nő. Az utóbbi években tapasztalt javulások ellenére a cardiovascularis betegségek a cukorbetegek morbiditásának és mortalitásának vezető okai. A cukorbetegség fennállása önmagában olyan cardiovascularis veszélyeztetettséget jelent, mintha ismert érbetegsége lenne a betegnek. A diabeteses dyslipidaemia jellemzői a magas éhgyomri és postprandialis triglicerid-, alacsony HDL-koleszterin-szint, valamint a kissé emelkedett LDL-koleszterin-szint mellett az atherogen kicsi-súrú, azaz a small-dense LDL nagy aránya. Az atherogen dyslipidaemiának ezen komponensei nem egymástól független eltérések, hanem egymással szorosan összefüggnek. Az utóbbi évek kutatási eredményei a small-dense LDL és az alacsony HDL káros hatásának elismerése mellett igazolták a trigliceridben gazdag lipoproteinek és azok remnantjainak atherogenitását, továbbá kimutatták, hogy a kulcs a trigliceridben gazdag lipoproteinek májban történő túltermelése és késleltetett lebontása. Ennek metabolizmusában meghatározó szerepe van a lipoproteinlipáznak, amelynek múködését az ApoA5 fokozza, az ApoC3 pedig gátolja. Ez utóbbi funkciócsökkenését okozó mutáció a szívinfarktus kockázatát csökkenti, míg az ApoA5 funkciócsökkenéssel járó mutációja a trigliceridben gazdag lipoproteinszintet 60\%-kal emeli és a szívinfarktus kockázatát 2,2-szeresére fokozza. Diabetes mellitus, inzulinrezisztencia, elhízás, metabolikus szindróma esetén az LDL-koleszterinnél a veszélyeztetettségnek jobb markere a non-HDL-koleszterin. Ezt úgy számolhatjuk ki, hogy az összkoleszterinből kivonjuk a HDL-koleszterin értékét. A non-HDL-koleszterin célértékeit úgy kapjuk meg, hogy az LDL-koleszterin-célértékekhez 0,8-et hozzáadunk, azaz nagy cardiovascularis kockázat esetén 3,3 mmol/l, igen nagy kockázat fennállásakor 2,6 mmol/l az elérendő szint. Diabeteses dyslipidaemia kezelésében is a statinok az elsőnek választandó gyógyszerek. Ugyanakkor ismert, hogy optimális (vagy célértékre történő) statinterápia esetén is jelentôs a residualis(lipid)-kockázat. Ennek mérséklésére a magas trigliceridszint és az alacsony HDL-koleszterin-szint kezelése kézenfekvő, amire a fibrátok adása kedvező hatású lehet. Statin mellé kombinációra a fenofibrát ajánlható. Orv. Hetil., 2016, 157(19), 746-752.
\end{abstract}

Kulcsszavak: diabetes mellitus, cardiovascularis kockázat, diabeteses dyslipidaemia, statin, fibrát

\section{Diabetic dyslipidaemia and the atherosclerosis}

The incidence and the public health importance of diabetes mellitus are growing continuously. Despite the improvement observed in the latest years, the leading cause of morbidity and mortality of diabetics are cardiovascular diseases. The diagnosis of diabetes mellitus constitutes such a high risk as the known presence of vascular disease. Diabetic dyslipidaemia is characterised by high fasting and postprandial triglyceride levels, low HDL level, and slightly elevated LDL-cholesterol with domination of atherogenic small dense LDL. These are not independent components of the atherogenic dyslipidaemia, but are closely linked to each other. Beside the known harmful effects of low HDL and small dense LDL, recent findings confirmed the atherogenicity of the triglyceride-rich lipoproteins and their remnants. It has been shown that the key of this process is the overproduction and delayed clearance of triglyceriderich lipoproteins in the liver. In this metabolism the lipoprotein lipase has a determining role; its function is accelerated by ApoA5 and attenuated by ApoC3. The null mutations of the ApoC3 results in a reduced risk of myocardial infarction, the loss-of-function mutation of ApoA5 was associated with a $60 \%$ elevation of triglyceride level and 2.2-times increased risk of myocardial infarction. In case of diabetes mellitus, insulin resistance, obesity, metabolic syndrome and chronic kidney disease the non-HDL-cholesterol is a better marker of the risk than the LDL-cholesterol. Its value can be calculated by subtraction of HDL-cholesterol from total cholesterol. Target values of nonHDL-cholesterol can be obtained by adding $0.8 \mathrm{mmol} / \mathrm{L}$ to the LDL-cholesterol targets (this means $3.3 \mathrm{mmol} / \mathrm{L}$ in high, and $2.6 \mathrm{mmol} / \mathrm{L}$ in very high risk patients). The drugs of first choice in the treatment of diabetic dyslipidae- 
mia are statins. Nevertheless, it is known that even if statin therapy is optimal (treated to target), a considerable residual (lipid) risk remains. For its reduction treatment of low HDL-cholesterol and high triglyceride levels is obvious by the administration of fibrates. In addition to statin therapy, fenofibrate can be recommended.

Keywords: diabetes mellitus, cardiovascular risk, diabetic dyslipidaemia, statin fibrate

Márk, L., Dani, Gy. [Diabetic dyslipidaemia and the atherosclerosis]. Orv. Hetil., 2016, 157(19), 746-752.

(Beérkezett: 2016. február 4.; elfogadva: 2016. február 25.)

\section{Rövidítések}

ApoB $=$ apolipoprotein $\mathrm{B} ; \mathrm{HDL}-\mathrm{C}=\mathrm{HDL}-$ koleszterin; $\mathrm{IFG}=$ kóros éhgyomri vércukor; LDL-C = LDL-koleszterin; T2DM = 2-es típusú diabetes mellitus; $\mathrm{TG}=$ triglicerid; TRLs $=$ trigliceridben gazdag lipoproteinek; VLDL = very low density lipoprotein

A diabetes mellitus népegészségügyi jelentősége már napjainkban is igen nagy, és az előrejelzések szerint ennek folyamatos növekedése várható a közeli, illetve a távoli jövőre nézve egyaránt. Ma a 2-es típusú diabetes mellitusban (T2DM) szenvedők számát a világon 350 millióra becsülik, számuk 2035-re hozzávetőlegesen 592 millióra nő [1]. 2010 és 2030 között 20\%-os emelkedés várható a fejlett, és 69\%-os a fejlődő országokban [2]. Jermendy és mtsai felmérése szerint napjainkban Magyarországon a 20-69 évesek körében 7,47\% a diabetes prevalenciája, és ehhez társul még a kóros éhgyomri vércukor (IFG), amely ugyanezen korosztály 4,39\%-át érinti [3]. Danaei és mtsai a diabetes globális trendjeit vizsgálva 2,7 millió beteg adatai alapján azt állapították meg, hogy a prevalencia a világon 1980-ban a férfiak és a nók körében 8,3 és 7,5\% volt, és ez 2008-ra 9,8 és 9,2\%-ra emelkedett. Ugyanezen időszak alatt az Amerikai Egyesült Államokban a férfiakban 18 , a nókben $23 \%$-os növekedést írtak le [4].

Becslések szerint T2DM fennállása 6 évvel rövidíti meg egy 50 éves beteg életét, és az élettartam ezen csökkenésének 58\%-a az érbetegségek gyakoriságnövekedése miatt van. A kórkép diagnosztizálása legalább kétszeresére emeli a cardiovascularis kockázatot [5]. A cukorbetegség fennállása önmagában olyan cardiovascularis veszélyeztetettséget jelent, mintha ismert érbetegsége lenne a betegnek. A nagyobb veszélyeztetettség több rizikófaktor együttes fennállásának a következménye (1. táblázat) [6], amelyek között a dyslipidaemiának megkülönböztetett szerepe van.

\section{A diabeteses dyslipidaemia gyakorisága}

A diabeteses dyslipidaemia alkotóelemei a magas éhgyomri és postprandialis triglicerid- (TG-), alacsony HDL-koleszterin- (HDL-C-) szint, valamint a kissé
1. táblázat | A cardiovascularis kockázati faktorok előfordulása 1-es és 2-es típusú diabeteses betegekben a nem diabetesesekhez képest [6]

\begin{tabular}{|c|c|c|}
\hline & T1DM & T2DM \\
\hline \multicolumn{3}{|l|}{ Dyslipidaemia } \\
\hline Hypertriglyceridaemia & + & ++ \\
\hline Alacsony HDL & - & ++ \\
\hline Small-dense LDL & - & ++ \\
\hline Magas ApoB & - & ++ \\
\hline Hypertonia & + & ++ \\
\hline Hyperinsulinaemia/inzulinrezisztencia & + & ++ \\
\hline Centrális obesitas & - & ++ \\
\hline Atherosclerosis a családi anamnézisben & - & + \\
\hline Dohányzás & - & - \\
\hline
\end{tabular}

emelkedett LDL-koleszterin-szint (LDL-C). Ez utóbbira az atherogen kicsi-sürü, azaz a small-dense LDL nagy aránya a jellemző (1. ábra, 1. táblázat).

A lipideltérések gyakorisága változó, nagymértékben függ a vizsgált populációtól. Magyar tanulmányban, általános populációban 8769 betegben a magas TG gyakorisága $37 \%$, az alacsony HDL-C-é $28 \%$, a kettő együtt az esetek 14\%-ában fordul elő. Statinkezeltekben (1373 fó) a magas TG 45\%, az alacsony HDL-C 27\%, a kettő együtt 16\%-os gyakoriságú volt [7]. Metabolikus szindrómás betegekben a Botnia vizsgálatban a magas TG és

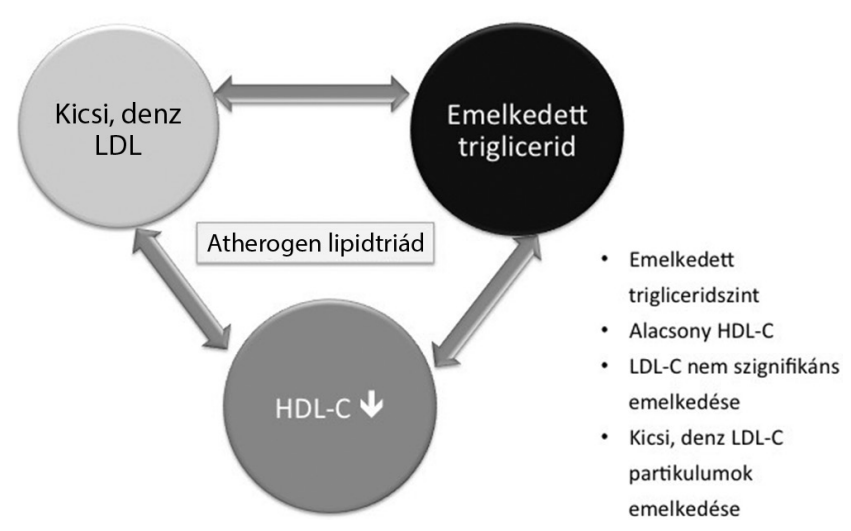

1. ábra $\mid$ Az atherogen dyslipidaemia - lipidtriád 


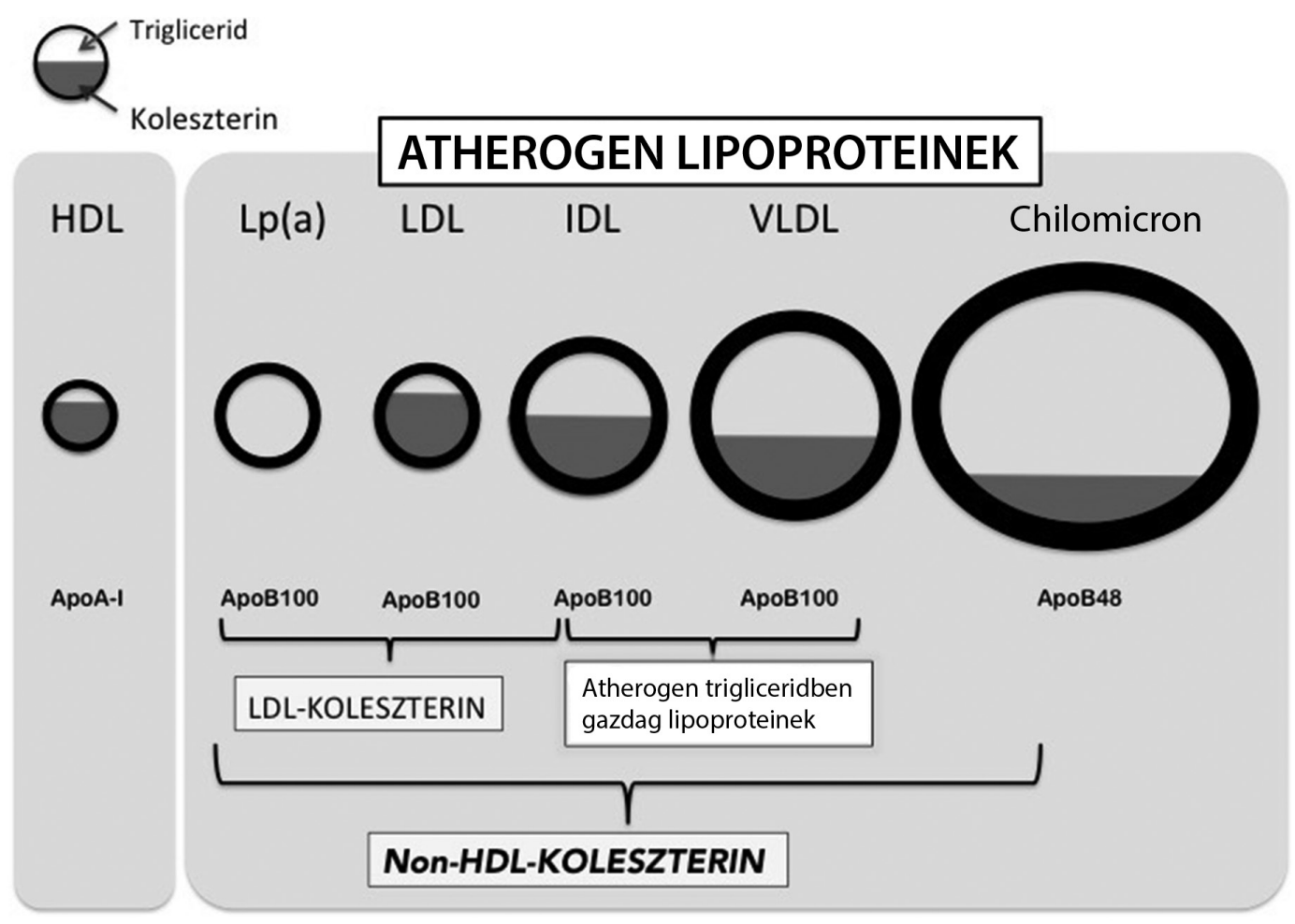

2. ábra

A non-HDL-C a plazma atherogen rés
protein $\mathrm{B}$ tartalmát is magában foglalja

alacsony HDL-C együttes előfordulása (TG>1,7 mmol/1, valamint HDL-C $<0,9 \mathrm{mmol} / \mathrm{l}$ férfiakban és $<1,15 \mathrm{mmol} / 1$ nőkben) 54\%-os gyakoriságú volt férfiak és 56\% nők esetén [8]. Statinnal kezelt T2DM-betegekben a közelmúltban 35-50\%-os gyakoriságúnak találták a dyslipidaemiát $[9,10]$.

\section{Diabeteses dyslipidaemia: a trigliceridben gazdag lipoproteinek metabolizmusa}

Az atherogen dyslipidaemia komponensei nem egymástól független eltérések, hanem egymással szorosan összefüggnek. Kevés a reverz koleszterintranszportban részt vevő HDL-C, sok az atherogen small-dense LDL. A TG-ben gazdag lipoproteinek (TRLs) metabolizmusának megváltozása az egyik kulcsa az atherogenitásnak. Minden TRGs-részecske tartalmaz egy apolipoprotein B (ApoB) molekulát. Ez ApoB48 a bélben képződő chilomicronokban és chilomicron remnantokban, a VLDL, IDL és LDL esetén pedig ApoB100 (2. ábra).

Az étkezéssel bekerülő lipidek hidrolizálódnak a bél lumenében, innen az enterocyták felveszik őket, majd a chilomicronokba épülnek. A szervezetbe kerülő lipidek beépülésének másik útja, hogy lipidcseppecskék formájában a citoszolba kerülnek, és ezek később, éhezési időszakban, az enterocytákban szekretálódnak. Innen a TG hidrolizálódik, a szabad zsírsavak az endoplazmás reticulumba kerülnek és lipoproteinekkel szekretálódnak. A lipidek tárolásának és mobilizálódásának ez a formája ma- gyarázza, hogy a szérum TG-szintjének emelkedése nem mindig közvetlenül az étkezéstől függ.

A chilomicronok kiválasztását legnagyobb mértékben az inzulin gátolja (T2DM-ben ennek kiemelt jelentősége van), de a folyamatban szerepe van a GLP-1-nek és a DPP-4-nek, a polifenolresveratrolnak, a táplálékkal bevitt lipidek mennyiségének, valamint a bél mikrobiom összetételének is. Ezen mechanizmusok múködése is megváltozik diabetesben. Ugyanakkor a betegségre jellemző dyslipidaemia kulcsfaktora a magas TG-szint, amelynek oka a VLDL-túltermelés [11].

\section{Diabeteses dyslipidaemia és atherosclerosis}

A diabeteses dyslipidaemia atherogenitása a small-dense LDL mellett a TRLs és azok remnantjainak szintjétől függ. Utóbbiakból a májban történő túltermelés van, és késleltetett a lebontásuk. A TRLs metabolizmusában meghatározó szerepe van a lipoproteinlipáznak, amelynek múködését az ApoA5 fokozza, az ApoC3 pedig gátolja (3. ábra). Az ApoA5 „loss-of-function” mutációja a TRLs-szintet $60 \%$-kal emeli, a szívinfarktus kockázatát 2,2-szeresére fokozza [12]. Az ApoC3 funkciócsökkenését okozó mutáció és a koszorúér-betegség kapcsolatát több mint 100 ezer beteg genetikai vizsgálata alapján tanulmányozták. Az eredmények szerint a lipoproteinlipázt gátló ApoC3 múködésének kiesése a TRLs-szint 39\%-os, a szívinfarktus-kockázat 40\%-os csökkenésével jár [13]. 


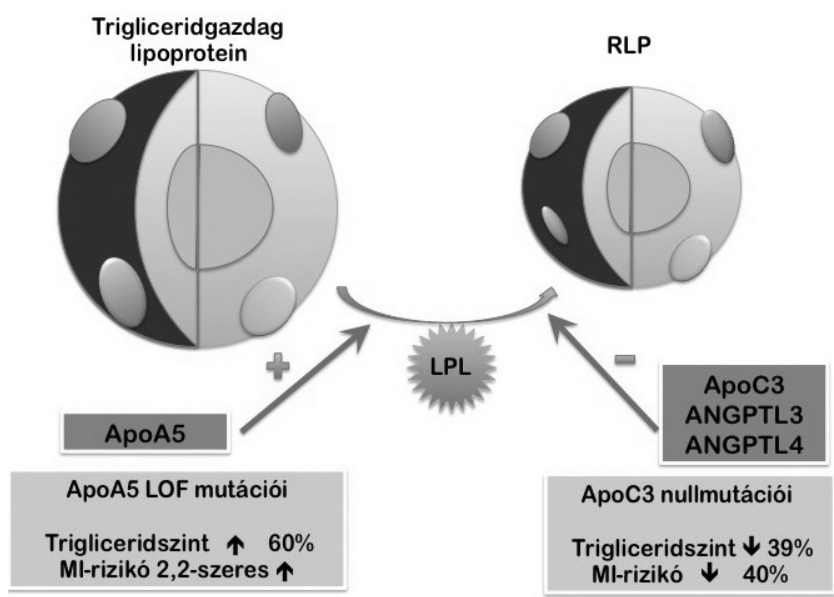

3. ábra

A lipoproteinlipáz szabályozza a TG-ben gazdag lipoproteinek remnant lipoproteinné (RLP) alakulás folyamatát, az enzim múködését befolyásoló apoproteinek mutációi a szívinfarktus kockázatát emelik vagy csökkentik

\section{A non-HDL-koleszterin (non-HDL-C) jelentősége cukorbetegségben, a non-HDL-C és LDL-C fontosságának összehasonlítása}

Az átlagpopulációban a cardiovascularis veszélyeztetettség általánosan elfogadott legfontosabb jelzője az LDLC. Bár a diabeteses dyslipidaemiának nem a magas LDL$\mathrm{C}$ a fó jellemzője, az ajánlások szerint cukorbetegek lipidcsökkentő kezelésében is az LDL-C-szint-célértékek elérése az elsődleges.

Nemcsak az LDL-részecskék száma, hanem azok nagysága (small-dense LDL) és oxidációs hajlama is fontos az atherosclerosis folyamatában. A TG-szint megnövekedésével járó betegségekben és állapotokban a cardiovascularis valós kockázatot más markerek jobban tudják jelezni, mint az LDL-C. Az apolipoprotein B (ApoB) atherogen jelentősége igazolt. Minden atherogen részecske tartalmaz ApoB-t, csak a védő hatású HDL nem. Az LDL és ApoB szintje a nem magas TG-tartományban párhuzamosan változik. Ugyanakkor, ha az LDL-C-szintet a Friedewald-képlet alapján kalkulációval állapítjuk meg (LDL-C = összkoleszterin - HDL-C - TG/2,2), akkor magas TG-szint esetén (4,0-4,5 feletti értéknél nem is szabad használni a képlelet) vagy sok small-dense LDL esetén az LDL-C szintjénél az ApoB meghatározása pontosabban jellemezné a valós veszélyeztetettséget. Az ApoB meghatározására a mindennapi gyakorlatban nincsen lehetőség.

Dán kutatók mendeli randomizációs megfigyelésekből azt feltételezték, hogy a genetikai okból emelkedett nem éhgyomri remnant koleszterin (a TGLs koleszterintartalma, ami éhgyomri helyzetben a VLDL és az IDL koleszterintartalma, nem éhgyomri esetben a chilomicron remnantoké is) az ISZB fellépésének valószínűségét emeli függetlenül az alacsony HDL-C-szinttől. Több mint 73 ezer koppenhágai beteg 34 éves követése és genetikai vizsgálata alapján azt találták, hogy a nem éhgyomri remnant koleszterin $1 \mathrm{mmol} / \mathrm{l}$ emelkedése 2,8-szeresére emeli a koszorúér-betegség valószínúségét [14, 15].

Boekholdt és mtsai statinos vizsgálatokban szereplő több mint 60 ezer beteg adatait felölelő metaanalízisükben azt vizsgálták, hogy az LDL-C-nek, az ApoB-nek és non-HDL-C-nek milyen cardiovascularis eseményt elöre jelző ereje van. A HR 1 SD növekedésre 1,13 volt az LDL-C (95\% CI: 1,10-1,17), 1,16 a non-HDL-C (95\% CI: $1,12-1,19)$ és 1,14 az ApoB (95\% CI: $1,11-1,18)$ esetében. Ezek a különbségek szignifikánsan magasabbak a non-HDL-C esetében, mint az LDL-C ( $\mathrm{p}=0,002)$ és az ApoB $(\mathrm{p}=0,02)$. Az ApoB és LDL-C közötti különbség nem volt szignifikáns $(\mathrm{p}=0,21)$ [16].

A MULTI GAP (MULTI Goal Attainment Problem) 2010 és 2011 vizsgálatokban részt vett 2674 cukorbetegben a non-HDL-C-célérték elérése a TG-szinttel folyamatos, fordított arányú összefüggést mutatott, ugyanakkor az LDL-C-célérték elérése és TG kapcsolatát elemezve $2,5 \mathrm{mmol} / \mathrm{l}$ trigliceridszint felett egy plató alakult ki. A TG-szint emelkedésével a non-HDL-C és TRL változása folyamatos volt, az LDL-C platót mutatott 2,0-2,5 mmol/1 TG felett. A 4. ábra a $2,5 \mathrm{mmol} / \mathrm{l}$ LDL-koleszterin-célértékeket elért betegek LDL-, nonHDL- és HDL-koleszterin-szint-változását mutatja be a trigliceridszintek függvényében. (Az ábrán a non-HDLC értéke az egyes oszlopok két alsó részének összeadásával kapható meg.) Multivariációs modellben a non-HDL-koleszterin-szint-célértékek elérése a TGkoncentrációval, a nem szakorvosi gondozással, a nem megfelelően kezelt hypertoniával volt fordítottan arányos. A TG-szintek sokkal szorosabban függtek össze a non-HDL-C-, mint az LDL-C-célértékek elérésével (OR per 1 SD emelkedésben a log-trigliceridben 0,74 , 95\% CI 0,61-0,89 volt az LDL-C, $0,49,95 \%$ CI $0,38-$ 0,61, a non-HDL-C-célérték elérésében) [17, 18]. Ezek

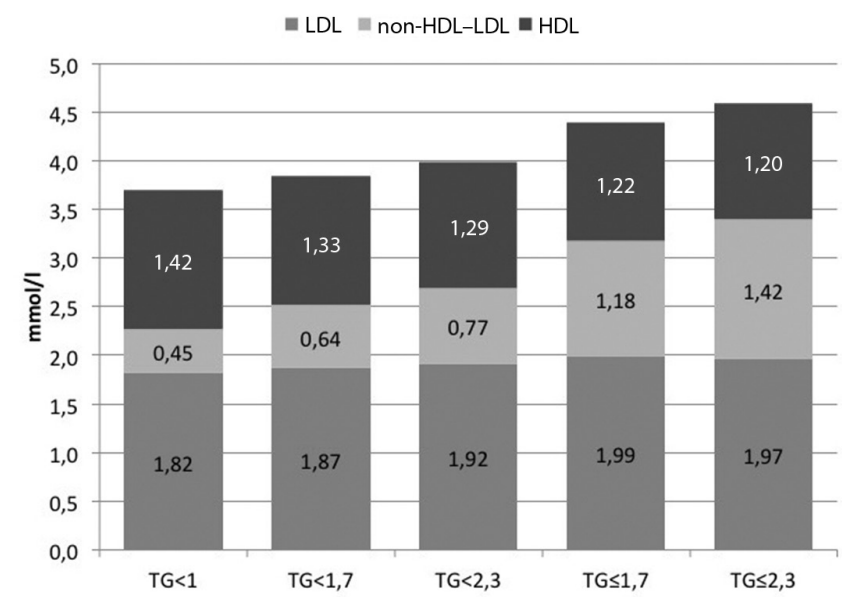

4. ábra $\quad$ A MULTI GAP 2010-2011 vizsgálat 2,5 mmol/1 LDL-koleszterin-célértéket elért diabeteses betegeinek LDL-, non-HDL- és HDL-koleszterin-szint változása a trigliceridszintek függvényében 
az eredmények azt sugallják, hogy T2DM-betegekben a lipidcélértékek elérésének esélye 2,5 mmol/1 TG-szint felett csökken, valamint arra hívják fel a figyelmet, hogy magasabb TG esetén a non-HDL-C-szint figyelembevételével jobban tudjuk csökkenteni a betegek veszélyeztetettségét.

\section{Mit mérjünk diabeteses dyslipidaemiában? A non-HDL-C célértéke}

Magas TG-szint esetén, diabetes mellitusban, inzulinrezisztenciában, obesitasban, metabolikus szindrómában az LDL-C-nél jobb markere a veszélyeztetettségnek a non-HDL-C (2. ábra). Ennek szintjét egyszerú számítással tudjuk meghatározni, az összkoleszterinből kivonjuk a HDL-C értékét [19-21]. Az Amerikai Egyesült Államokban múködő National Lipid Association a legújabb ajánlásában a non-HDL-C egyre gyakoribb alkalmazását favorizálja és a különböző veszélyeztetettségi kategóriákban megadott célértékek mellett meghatározza a gyógyszeres lipidcsökkentés elkezdésének határértékeit is [22]. A magyar konszenzusajánlásban a diabeteses beteg eleve a nagy kockázatú kategóriába sorolandó. Diabetesben az összkoleszterin célértéke 4,5 mmol/l, az LDL-C-é 2,5 mmol/l, a HDL-C-é férfiakban 1,1 $\mathrm{mmol} / 1$, nókben $1,3 \mathrm{mmol} / 1$, a TG-é pedig $1,7 \mathrm{mmol} / 1$. Igen nagy kockázat fennállásakor összkoleszterin 3,5 mmol/1, az LDL-C tekintetében pedig 1,8 mmol/1 az elérendő érték [23]. A non-HDL-C célértékét úgy kapjuk meg, hogy az LDL-C-éhez hozzáadunk 0,8-et.

\section{A lipidcsökkentés klinikai haszna diabetesben}

Minden T2DM-betegben hatékony és erőteljes multifaktoriális kezelést kell alkalmazni, azaz meg kell próbálni az összes kockázati faktort (dyslipidaemia, hypertonia, hyperglykaemia és inzulinrezisztencia, dohányzás) optimálisan kezelni. A Steno-2 vizsgálat 13,3 éves utánkövetéssel azt igazolta, hogy az intenzív, több kockázati tényezőre ható kezelés hatására kedvezőbb a vascularis szövődmények előfordulása és a halálozás. A vizsgálatban jelentős különbség volt a célértékek elérésében a két (intenzíven és szokásos módon kezelt) vizsgálati ágban a különböző rizikófaktorok tekintetében. A legkedvezőbb elérési arány a koleszterinszintekre volt, ezt követte a hypertonia, majd a $\mathrm{HbA}_{\mathrm{lc}}$ [24]. Yudkin és mtsai elemzése a különböző intervenciós és epidemiológiai vizsgálatok eredményei alapján az egy cardiovascularis esemény megelőzéséhez szükséges kezelendő betegszámot hasonlítja össze egyes rizikófaktorok esetében. A koleszterinszint $1 \mathrm{mmol} / \mathrm{l}$-es csökkentésével 59,5\%, a vérnyomás $10 / 5 \mathrm{Hgmm}$-es csökkentésével $61,8 \%$ és a $\mathrm{HbA}_{\mathrm{lc}} 0,9 \%$ csökkentésével 140,3 beteg 5 éves kezelésével lehet egy halálos és nem halálos szívinfarktust vagy hirtelen szívhalált megelőzni [25].

\section{Lipidcsökkentő kezelés diabetesben}

A statinok diabetesben is az elsőnek választandó szerek. Ennek evidenciáit nagy statinos vizsgálatok alcsoportelemzései és az első, kizárólag cukorbetegeken végzett lipidcsökkentő vizsgálat, a Collaborative Atorvastatin Diabetes Study (CARDS) szolgáltatják. Megkérdőjelezhetetlen a Cholesterol Treatment Trialists' Collaborators (CTTC) diabetesesekkel foglalkozó metaanalízise is, amely 14, statinnal történt vizsgálat 18686 cukorbetegének 4,3 éves átlagos követési ideje alatt azt igazolta, hogy statin adásával $1 \mathrm{mmol} / 1$ LDL-C-szint-csökkentés hatására az összhalálozás 9\%-kal, a nagy vascularis események gyakorisága $21 \%$-kal, a szívinfarktus és/vagy coronariaeredetű halálozás $22 \%$-kal, a coronariarevascularisatio 25\%-kal, a stroke gyakorisága $21 \%$-kal csökkent. A diabeteseseken észlelt kedvező hatások hasonlóak voltak éreseményen már átesett vagy attól mentes betegekben. 1000, statint szedő cukorbetegen 5 év alatt 42 -vel kevesebb (95\% CI: 30-55) éresemény történt [26]. Újabban sok közlés van a statinok új keletű diabetest okozó hatásáról. A pontos mechanizmus nem ismert. Egyértelmúen leszögezhető, hogy a statinok alkalmazásának klinikai haszna jelentősen felülmúlja esetleges diabetest okozó hatásukat, ezért hiba lenne, ha a rászoruló betegek e megfontolásból nem kapnák a megfelelő lipidcsökkentő kezelést [27-29].

A koleszterin felszívódását szelektíven gátló ezetimib a statinterápiához adva ráadásul körülbelül 27\%-kal csökkenti az LDL-C-t, kedvezően befolyásolja a többi lipidparamétert és nem rontja a cukoranyagcserét [30]. Nagy klinikai vizsgálatban igazolt az ezetimib adásának cardiovascularis eseményeket csökkentő hatása [31].

A statinkezelés vagy statin + ezetimib után maradó magas TG- és alacsony HDL-C-szintet residualislipid-rizikónak nevezzük. Nincs olyan nagy klinikai vizsgálat, amely statinterápiában részesülő T2DM-betegekben a diabeteses dyslipidaemia fennállásának függvényében további lipidcsökkentővel történő kezelés hatását elemezné. A napi gyakorlatban gyakran találkozunk olyan betegekkel, akiknek statinterápia mellett residualislipidkockázatuk maradt. Erre a betegcsoportra vonatkozó terápiát illetően, nagy vizsgálatból származó direkt bizonyíték hiányában, alcsoportelemzésre vagy metaanalízisre kell hagyatkoznunk.

A magas TG és alacsony HDL-C kezelésére a fibrátok alkalmasak. Mivel statin mellé adnánk, a gyógyszercsoportból a fenofibrát az elsőnek ajánlható, mert ezzel a szerrel történtek megfelelő klinikai vizsgálatok, és ez a szer kombinálható biztonságosan statinokkal.

Az ACCORD-Lipid 5518 diabeteses betegen történt. Ezek 20 vagy $40 \mathrm{mg}$ simvastatin adása után a statin melletti a további lipidszintektől függetlenül kerültek fenofibrát- vagy placeboágra randomizálásra. A primer végpont (nem halálos szívinfarktus, nem halálos stroke és halálos cardiovascularis esemény) 8\%-os csökkenése nem volt szignifikáns. Ugyanakkor egy előre meghatározott 
941 fós alcsoportban (amikor a TG-szint 2,3 mmol/1 felett és a HDL-C $0,88 \mathrm{mmol} / \mathrm{l}$ alatt volt) a simvastatin mellé adott fenofibrát a primer végpont gyakoriságát már jelentősebben, 31\%-kal csökkentette $(\mathrm{p}=0,057)$ [32]. Mire vonatkozik ez a nem szignifikáns eltérést mutató p-érték? Az alcsoportelemzés a fibráthatást hasonlítja össze a dyslipidaemiás és a nem dyslipidaemiás csoportban, hogy fenofibrát adása eltérően befolyásolja-e a cardiovascularis események alakulását a dyslipidaemiás és az összes többi betegen. Ennek az összehasonlításnak a szignifikanciaszintje 0,057. A közismerten szigorú amerikai gyógyszerügyi hatóság, az FDA (Food and Drug Administration) honlapjáról letölthető elemzésben [33] összehasonlításra kerül a dyslipidaemiás és a nem dyslipidaemiás alcsoportokban külön is a statinnal és a statin + fenofibráttal kezeltek szignifikanciaszintje, amely statisztikailag szignifikánsnak bizonyult $(\mathrm{p}=0,03)[33,34]$. Ez konzisztens a korábbi fibrátvizsgálatok (Helsinki Heart Study, VA-HIT, BIP és FIELD) atherogen dyslipidaemiás (magas TG- és alacsony HDL-C-szintü) alcsoportjainak eredményeivel (5. ábra) [35].

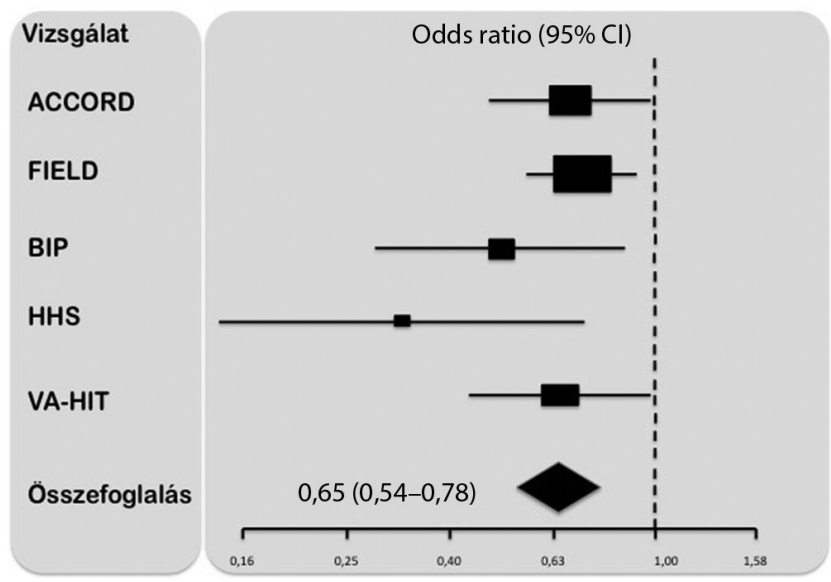

5. ábra A fibrátokkal történt klinikai vizsgálatok alcsoportelemzései iga-
zolják, hogy a fibrátok atherogen dyslipidaemia esetén $(\mathrm{TG}>2,3$
$\mathrm{mmol} / 1$ és $\mathrm{HDL}<1,03 \mathrm{mmol} / \mathrm{l})$ csökkentik a cardiovascularis
kockázatot

Ennek alapján a residualislipid-kockázat csökkentésére statinkezelés mellett magas TG- és alacsony HDL-Cszint esetén fenofibrát javasolt [36], amely ajánlás a legújabb európai kardiológus- és atherosclerosistársaságok (ESC/EAS) által kiadott dyslipidaemia-irányelvekben is szerepel [21].

Statin vagy statin és fenofibrát mellett maradt magas TG-szint esetén ómega-3 zsírsav adása jöhet szóba. Nagy betegszámú klinikai vizsgálatok most vannak folyamatban. Az elméletileg adható gyanta és niacin Magyarországon nincsen forgalomban. A most bevezetés elött álló PCSK9-gátlók elsősorban az LDL-C csökkentésére alkalmasak. A HDL-C emelését célzó CETP-gátlók alkalmazhatósága a folyamatban lévő klinikai végpontú vizsgálatok eredményétől függ.
Anyagi támogatás: A kutatómunka és a közlemény megírása anyagi támogatásban nem részesült.

Szerzői munkamegosztás: M. L.: Irodalmazás, a kézirat megszövegezése. D. Gy.: Irodalmazás, az ábrák elkészítése. A cikk végleges változatát mindkét szerző elolvasta és jóváhagyta.

Érdekeltségek: A szerzőknek nincsenek érdekeltségeik.

\section{Irodalom}

[1] Zimmet, P. Z., Magliano, D. J., Herman, W. H., et al.: Diabetes: a 21 st century challenge. Lancet Diabetes Endocrinol., 2014, 2(1), 56-64.

[2] Shaw, J. E., Sicree, R. A., Zimmet, P. Z.: Global estimates of the prevalence of diabetes for 2010 and 2030. Diabetes Res. Clin. Pract., 2010, 87(1), 4-14.

[3] Jermendy, G., Nádas, J., Szigethy, E., et al.: Prevalence rate of diabetes mellitus and impaired fasting glycemia in Hungary: crosssectional study on nationally representative sample of people aged 20-69 years. Croat. Med. J., 2010, 51(2), 151-156.

[4] Danaei, G., Finucane, M. M., Lu, ., et al.: National, regional, and global trends in fasting plasma glucose and diabetes prevalence since 1980: systematic analysis of health examination surveys and epidemiological studies with 370 country-years and 2.7 million participants. Lancet, 2011, 378(9785), 31-40.

[5] Emerging Risk Factors Collaboration, Sarwar, N., Gao, P., Seshasai, S. R., et al.: Diabetes mellitus, fasting blood glucose concentration, and risk of vascular disease: a collaborative meta-analysis of 102 prospective studies. Lancet, 2010, 375(9733), 22152222.

[6] Chait, A., Bierman, E. L.: Pathogenesis of macrovascular disease in diabetes. In: Kahn, C. R., Weir, G. C. (eds.): Joslin's diabetes mellitus. 13th edition. Lea and Febiger, Philadelphia, 1994.

[7] Márk, L., Kiss, Z., Nagy, L., et al.: Beyond decreasing LDL-cholesterol: changes in HDL-cholesterol and trigliceride in patients with high risk. [Az LDL-koleszterin-szint csökkentésen túl: a HDL-koleszterin- és trigliceridszintek alakulása nagy kockázatú betegek körében.] Metabolizmus, 2009, 7(1), 33-38. [Hungarian]

[8] Isomaa, B., Almgren, P., Tuomi, T., et al.: Cardiovascular morbidity and mortality associated with the metabolic syndrome. Diabetes Care, 2001, 24(4), 683-689.

[9] Feher, M., Greener, M., N. Munro, N.: Persistent hypertriglyceridemia in statin-treated patients with type 2 diabetes mellitus. Diabetes Metab. Syndr. Obes., 2013, 6, 11-15.

[10] Leiter, L. A., Lundman, P., da Silva, P. M., et al.: Persistent lipid abnormalities in statin-treated patients with diabetes mellitus in Europe and Canada: results of the Dyslipidaemia International Study. Diabet. Med., 2011, 28(11), 1343-1351.

[11] Taskinen, M. R., Borén, J.: New insights into the pathophysiology of dyslipidemia in type 2 diabetes. Atherosclerosis, 2015, 239(2), 483-495.

[12] Do, R., Stitziel, N. O., Won, H. H., et al.: Exome sequencing identifies rare LDLR and APOA5 alleles conferring risk for myocardial infarction. Nature, 2015, 518(7537), 102-106.

[13] TG and HDL Working Group of the Exome Sequencing Project, National Heart, Lung, and Blood Institute, Crosby, J., Peloso, G. M., Auer, P. L., et al.: Loss-of-function mutations in APOC3, triglycerides, and coronary disease. N. Engl. J. Med., 2014, 371(1), 22-31.

[14] Varbo, A., Benn, M., Tybjarg-Hansen, A., et al.: Remnant cholesterol as a causal risk factor for ischemic heart disease. J. Am. Coll. Cardiol., 2013, 61(4), 427-436. 
[15] McPherson, R.: Remnant cholesterol: "Non-(HDL-C + LDLC)" as a coronary artery disease risk factor. J. Am. Coll. Cardiol., 2013, 61(4), 437-439.

[16] Boekholdt, S. M., Arsenault, B. J., Mora, S., et al.: Association of LDL cholesterol, non-HDL cholesterol, and apolipoprotein B levels with risk of cardiovascular events among patients treated with statins: a meta-analysis. JAMA, 2012, 307(12), 1302-1309.

[17] Márk, L., Reiber, I., Paragh, Gy., et al.: Importance of non-HDLcholesterol determination in diabetic patients. [A non-HDL-koleszterin vizsgálatának jelentősége cukorbetegekben.] Metabolizmus, 2012, 10(5), 285-292. [Hungarian]

[18] Mark, L., Vallejo-Vaz, A. J., Reiber, I., et al.: Non-HDL cholesterol goal attainment and its relationship with triglyceride concentrations among diabetic subjects with cardiovascular disease: a nationwide survey of 2,674 individuals in Hungary. Atherosclerosis, 2015, 241(1), 62-68.

[19] Reiber, I., Paragh, Gy., Márk, L., et al.: The most atherogenic cholesterol. [Az igazán atherogen koleszterin.] Metabolizmus, 2011, 9(3), 146-150. [Hungarian]

[20] Reiber, I., Mezo, I., Mark, L., et al.: The good, the bad, and the atherogenic. Letter to the editor. J. Am. Coll. Cardiol., 2012, 59(14), 1333-1334.

[21] Reiner, Z., Catapano, A. L., De Backer, G., et al., The Task Force for the management of dyslipidaemias of the European Society of Cardiology (ESC) and the European Atherosclerosis Society (EAS): ESC/EAS Guidelines for the management of dyslipidaemias. Eur. Heart J., 2011, 32(14), 1769-1818.

[22] Jacobson, T. A., Ito, M. K., Maki, K. C., et al.: National Lipid Association recommendations for patient-centered management of dyslipidemia: part 1 - executive summary. J. Clin. Lipidol., $2014,8(5), 473-488$

[23] Recommendations of the 6th Hungarian Cardiovascular Consensus Conference. [A VI. Magyar Kardiovaszkuláris Konszenzus Konferencia ajánlásai.] Metabolizmus, 2015, 13(1), 1-55. [Hungarian]

[24] Gaede, P., Lund-Andersen, H., Parving, H. H., et al.: Effect of a multifactorial intervention on mortality in type 2 diabetes. N. Engl. J. Med., 2008, 358(6), 580-591.

[25] Yudkin, J. S., Richter, B., Gale, E. A.: Intensified glucose lowering in type 2 diabetes: time for a reappraisal. Diabetologia, 2010, 53(10), 2079-2085.

[26] Cholesterol Treatment Trialists' (CTT) Collaborators, Kearney, $P$. M., Blackwell, L., Collins, R., et al.: Efficacy of cholesterol-lowering therapy in 18,686 people with diabetes in 14 randomised trials of statins: a meta-analysis. Lancet, 2008, 371(9607), 117125.

[27] Sattar, N., Preiss, D., Murray, H. M., et al.: Statins and risk of incident diabetes: a collaborative meta-analysis of randomised statin trials. Lancet, 2010, 375(9716), 735-742.

[28] Preiss, D., Seshasai, S. R., Welsh, P., et al.: Risk of incident diabetes with intensive-dose compared with moderate-dose statin therapy: a meta-analysis. JAMA, 2011, 305(24), 2556-2564.

[29] Van de Woestijne, A. P., van der Graaf, Y., Westerink, J., et al.: Effect of statin therapy on incident type 2 diabetes mellitus in patients with clinically manifest vascular disease. Am. J. Cardiol., 2015, 115(4), 441-446.

[30] Bays, H. E.: Lowering low-density lipoprotein cholesterol levels in patients with type 2 diabetes mellitus. Int. J. Gen. Med., $2014,7,355-364$.

[31] Cannon, C. P., Blazing, M. A., Giugliano, R. P., et al.: Ezetimibe added to statin therapy after acute coronary syndromes. N. Engl. J. Med., 2015, 372(25), 2387-2397.

[32] ACCORD Study Group, Ginsberg, H. N., Elam, M. B., Lovato, L. C., et al.: Effects of combination lipid therapy in type 2 diabetes mellitus. N. Engl. J. Med., 2010, 362(17), 1563-1574.

[33] FDA Endocrinologic and Metabolic Drugs Advisory Committee meeting, May 19, 2011, Briefing information. http://www.fda. gov/AdvisoryCommittees/CommitteesMeetingMaterials/ Drugs/EndocrinologicandMetabolicDrugsAdvisoryCommittee/ucm 255549.htm

[34] Tenenbaum, A., Fisman, E. Z.: Fibrates are an essential part of modern anti-dyslipidemic arsenal: spotlight on atherogenic dyslipidemia and residual risk reduction. Cardiovasc. Diabetol., $2012,11,125$.

[35] Sacks, F. M., Carey, V. J., Fruchart, J. C.: Combination lipid therapy in type 2 diabetes. N. Engl. J. Med., 2010, 363(7), 692694.

[36] Agniar, C., Alegria, E., Bonadonna, R. C., et al.: A review of the evidence on reducing macrovascular risk in patients with atherogenic dyslipidaemia: A report from an expert consensus meeting on the role of fenofibrate-statin combination therapy. Atheroscler. Suppl., 2015, 19, 1-12.
(Márk László dr., Gyula, Semmelweis u. 1., 5700 e-mail: mark@pandy.hu)

\section{Eladó praxis Németországban}

\section{Bajorországban az osztrák határtól egy kilométerre 40 éve müködő praxishely a város központi részében átadó komplett felszereléssel.}

(Computerek, ultrahang, doppler ergotherapia, stb.) Az átadáshoz jogi segítségre is van lehetőség.

$$
\begin{aligned}
& \text { Érdeklődés: Magyarországon: +3630/5263-209 } \\
& \text { Németországban: } 0049 \text { 8679171555 }
\end{aligned}
$$

